\title{
Phloem sap in fire-damaged Scots pine trees provides instant forag- ing opportunities for Three-toed Woodpeckers Picoides tridactylus
}

Sav i floemet hos brandskadade tallar ger omedelbart tillgång till föda för tretåiga hackspettar Picoides tridactylus

\author{
TIMO PAKKALA, JARI KOUKI, MARKUS PIHA \& JUHA TIAINEN
}

\begin{abstract}
Three-toed Woodpeckers Picoides tridactylus are known to use phloem sap of conifer trees as a food resource mostly in springtime. A local pair instantly began to forage sap of Scots pine Pinus sylvestris trees that were damaged in a prescribed forest burning; before the fire they had used phloem sap elsewhere in their territory. During three weeks after the fire, the pair intensively used sap of Scots pines which were exposed to fire. The woodpeckers were probably attracted by nutrients induced by damage reaction of the burned pines. Rapid sap use of newly burned trees has not been described before, and it indicates behavioural plasticity how this woodpecker species can use resources in disturbance driven, dynamic forest environments.
\end{abstract}

Timo Pakkala, University of Helsinki, Lammi Biological Station, FI-16900 Lammi, Finland.

E-mail:timo.pakkala@hotmail.fi

Jari Kouki, University of Eastern Finland, School of Forest Sciences, P. O. Box 111, FI-80101 Joensuu, Finland. E-mail:jari.kouki@uef.fi

Markus Piha, Finnish Museum of Natural History LUOMUS, P. O. Box 17, FI-00014 University of Helsinki, Finland.E-mail: markus.piha@helsinki.fi

Juha Tiainen, Natural Resources Research Institute Finland, P. O. Box 2, FI-00791 Helsinki, Finland. E-mail: juha.tiainen@luke.fi

\section{Received 25 September 2017, Accepted 12 October 2017, Editor: Sören Svensson}

\section{Introduction}

Three-toed Woodpeckers Picoides tridactylus predominantly feed on arthropods, but especially in springtime they also use phloem sap of conifer trees (Ruge 1968, Glutz \& Bauer 1980, Cramp 1985, Pechacek 2006). Phloem sap is energy-rich and nutritionally valuable containing sugars, amino acids and minerals (Douglas 2006). Three-toed Woodpeckers can gain phloem sap by excavating often horizontal rows of small holes into the bark of living trees; these may be used during several years (Glutz \& Bauer 1980, Cramp 1985).

Three-toed Woodpeckers and some other woodpecker species favour areas with burned trees (see Fayt et al. 2005), but known situations are linked to increased amounts of insects gathered to the burned areas (Muona \& Rutanen 1994, Hyvärinen et al. 2005). Therefore, the woodpecker responses are generally detected not until the increase of local insect populations (Fayt et al. 2005).
Here we report a quick reaction of Three-toed Woodpeckers to move to a burned area and use the sap of the partially burned and damaged Scots pines Pinus sylvestris. We describe this previously undocumented phenomenon and discuss possible mechanisms and reasons for the observed patterns.

\section{Material and methods}

\section{Study area}

A prescribed burning was conducted on 10 May in 2016 in a forest area of ca. 4 ha within the southern boreal vegetation zone in, southern Finland $\left(61^{\circ}\right.$ $\left.12^{\prime} \mathrm{N} ; 25^{\circ} 09^{\prime} \mathrm{E}\right)$. Most of the trees were harvested from the area prior to the burning, but a group of Scots pines and scattered silver birches Betula pendula and Norway spruces Picea abies were left standing in the area that was mostly surrounded by coniferous dominated forests. 


\section{Three-toed Woodpeckers and their sap trees in the area}

The burned area was situated in the middle of a long-term territory of the Three-toed Woodpecker (Pakkala et al. 2017). Breeding and foraging activities of this pair were observed already earlier in the spring before the burning. Intensive mapping of sap trees within the territory was carried out by the author TP in 2015 and 2016. No old sap trees from the pre-burn time were situated in the newly burned area.

The size (diameter at breast height, DBH) of the sap trees in the burned area and the height of the charred zone on their bark from the ground were measured. The numbers, heights, and compass points of sap rows were monitored during field visits of $1-5$ hours $1,4,11,15,23$, and 43 days after the burning. The foraging behaviour of the Threetoed Woodpeckers and the time used to sap feeding were observed at the visits.

\section{Results}

\section{The sap tree use after burning}

The group of Scots pines in the burned area included 37 trees of the age of ca. 40 years within an area of 0.5 ha. The bark of several of the trees was charred, although usually only in the base to less than one meter above the ground (Figure 1). However, the charred surface reached a height of 2-3 meters but mostly on the southern sides of some trunks. The Three-toed Woodpeckers used a total of 11 trees to sap feeding during the period of 11 May to 22 June (Table 1). The DBH of selected trees varied between $20-28 \mathrm{~cm}$ and they had various amounts of charred surface in their trunks (Table 1, Figure 1). The Three-toed Woodpeckers used the

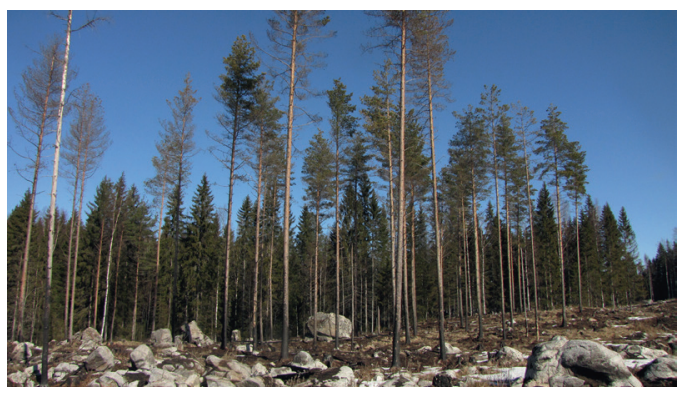

southern surfaces of the trunks in making the sap rows (Table 1, Figure 1) and generally pecked new rows above old ones.

The Three-toed Woodpecker pair was present in the area already in the next day after the burning, and the birds examined potential sap trees by scaling small areas of the bark of the pines, and some sap holes were also pecked to at least five of the trees (Table 2). Four days after the fire, the woodpeckers were detected to use several hours of foraging time pecking new sap rows and feeding on sap. The sap use was intensive until early June, and 23 days after the fire a total of 215 sap rows were made. The sap trees were visited also later in June, but the number of additional new rows was only 27 during the period 3-22 June (Table 2).

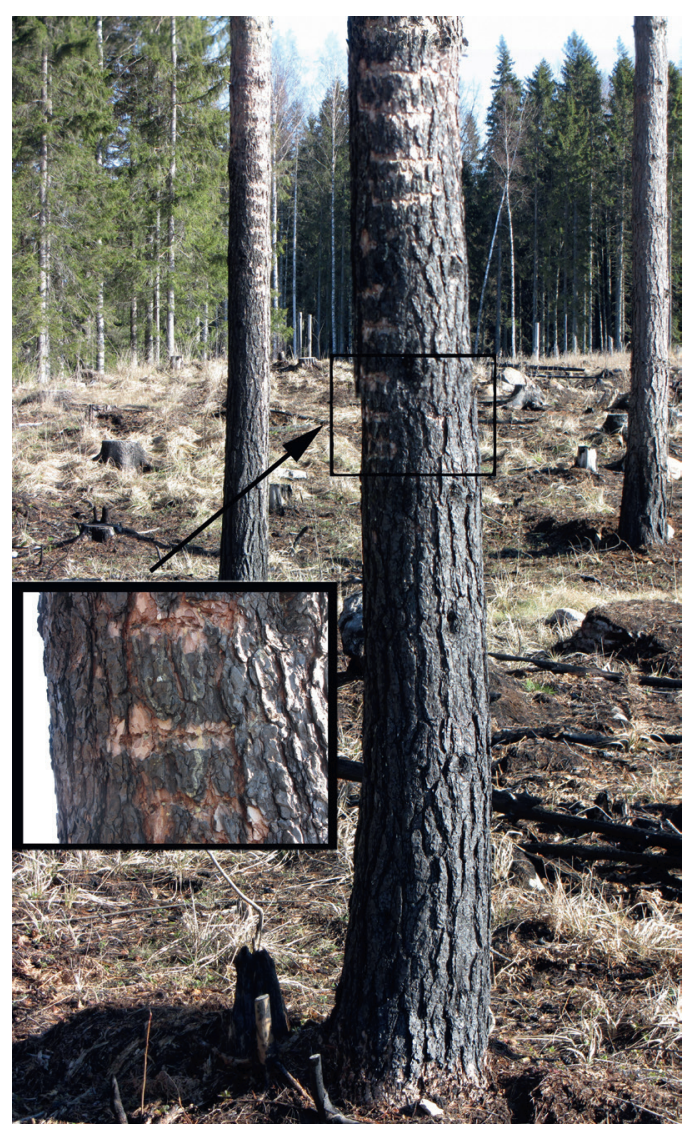

Figure 1 a) The group of Scots pines in the prescribed burning area; b) sap rows of the Three-toed Woodpecker in partially charred trunks of Scots pines. Photographs taken by the author JT.

(a) Tallgruppen på den forstliga brandytan i Evo i södra Finland; b) savrader på stammar av delvis förkolnade tallar. 


\section{Feeding behaviour}

The feeding behaviour of the woodpeckers was restricted to typical patterns of sap use with scaling narrow horizontal bands into the outermost layer of the trees, pecking small sap holes in the middle of these bands, and then drinking sap with their bills. The trunks of the partially charred pines were intact around the sap rows and there was some resin flow from the sap holes.

During the two weeks after the burning, the male and female were often observed together in the burning area, but mostly feeding at separate trees. In the later periods male and female were most often detected sap-feeding at separate time periods. Feeding behaviour connected to gathering insects (scaling irregular areas of bark, tapping, pecking larger irregular holes, probing, gleaning, etc.; see Pechacek 2006) was not observed, and no signs of this kind of behaviour were detected in the trunks of the pines in the burning areas. Neither were potential food item insects observed in the trunks or sap holes during the observation period.

\section{Discussion}

The Three-toed Woodpeckers instantly responded to burning and started to exploit damaged trees by feeding on the sap. This kind of pattern has not been described before. Before and at the time of the prescribed burning, the local pair was actively using the sap of Norway spruce trees in nearby forest areas, but they also searched trees for arthropod food. The area of the prescribed burning was not observed to be used for feeding prior to the burning. After the burning, the pair still occasionally used spruce sap trees, but the birds were observed to use substantial part of foraging time in sap feeding at the burned Scots pines.

Phloem sap is rich in nutrients and contains high concentrations of sugars that provide a good source of carbon and energy, nitrogen (mostly in the form of amino acids), and various minerals (e.g. Pate et al. 1998, Douglas 2006). Woodpeckers are known to select sap trees based on the individual properties of trees, e.g. sap amount and quality (Eberhard 2000, Núñes Montellano \& Blendinger 2016). Compared with insect larvae, the nitrogen of the phloem sap is, however, considerably lower quality because of low concentrations of several essential amino acids. The amounts of minerals, e.g. calcium, are also an order of magnitude smaller in phloem sap than in insects (Bukkens 1997, Pate et al. 1998, Douglas 2006).
The sap trees with increased stress levels or visible damages are likely to have higher amounts of nitrogen, amino acids or proteins in their phloem sap than healthy trees (see White 1984). In a forest fire, the trees are exposed to high temperatures that likely affect the composition of phloem sap. Alexou \& Dimitrakopoulos (2014) studied the shock and acclimation reactions of the Brutian pine Pinus brutia in a simulation of forest fire. They found a clear increase of non-soluble proteins in phloem already after two hours but particularly one day after the fire. The levels of these proteins were significantly higher still one week after the fire compared with the pre-fire situation. Phloem soluble sugars and amino acids also tended to accumulate one day after the fire, but their concentrations had significantly decreased a week after the fire. The phloem transport velocity also increased significantly after the fire, and it was still higher one day after the fire in comparison with the pre-fire situation. It is probable that the Three-toed Woodpeckers reacted to similar changes in the phloem of the burned Scots pines. The Three-toed Woodpeckers have been observed to favour partially burned pines for sap feeding several years after the fire (T. Pakkala, pers. obs.) indicating that also some long-term effects of fire exposure may be important.

Woodpeckers can also themselves induce increased sap flow by their feeding technique: new sap rows are often pecked above the old sap holes (e.g. Cramp 1985, Eberhard 2000) that is thought to be linked to the accumulation of sap in tree tissues above the old rows (Kilham 1964, Eberhard 2000). The Three-toed Woodpeckers used this technique in the burned study area, but it is also possible that the fire injured the tissue structures of the trees in a way that nutrients were blocked to be usable by the woodpeckers. Pecked sap rows were on the southern surfaces of the trees (Table 1) that corresponds the direction of the highest burned zones visible in the trunks and thus probably indicates the surfaces that experienced the highest temperatures during the fire. However, most of the sap rows of the Threetoed Woodpeckers in general are located on the southern surfaces of trees, probably for their beneficial thermal conditions (T. Pakkala, pers. obs.), and we do not know if the observed directionality of the sap rows in the burned area was related to the severity and damages that fire caused on trees.

The Three-toed Woodpeckers use phloem sap generally prior to nesting in spring (Ruge 1968, Glutz \& Bauer 1980, Cramp 1985, Pechacek 2006). The woodpeckers used the pine sap trees 
Table 1. The Scots pine trees of the burned area used by the Three-toed Woodpeckers in sap feeding. The tree number indicates the approximate order in which the trees were taken to sap use. Sap row information describes the situation at the end of the observation period on the 22 June.

Brandytans tallar, som ett par av tretåig hackspett använde för savkonsumtion. Trädets nummer hänvisar till den approximativa ordningen, $i$ vilken hackspettarna började utnyttja trädet. Informationen om savraderna avser situationen på slutet av observationsperioden den 22 Juni.

\begin{tabular}{|c|c|c|c|c|c|}
\hline $\begin{array}{l}\text { Tree } \\
\text { number }\end{array}$ & $\begin{array}{l}\text { Diameter at } \\
\text { breast height }\end{array}$ & $\begin{array}{l}\text { Height of the charred } \\
\text { bark from ground }\end{array}$ & $\begin{array}{l}\text { Number of sap } \\
\text { rows pecked }\end{array}$ & $\begin{array}{l}\text { Height zone of sap } \\
\text { rows }\end{array}$ & $\begin{array}{l}\text { Direction of } \\
\text { sap rows }\end{array}$ \\
\hline $\begin{array}{l}\text { Trädets } \\
\text { nummer }\end{array}$ & $\begin{array}{l}\text { Diameter vid } \\
\text { brösthöjd }\end{array}$ & $\begin{array}{l}\text { Förkolnade barkens } \\
\text { höjd från marken }\end{array}$ & $\begin{array}{l}\text { Antal } \\
\text { gjorda savrader }\end{array}$ & $\begin{array}{l}\text { Höjdbälte för } \\
\text { savraderna }\end{array}$ & $\begin{array}{l}\text { Riktning för } \\
\text { savraderna }\end{array}$ \\
\hline 1 & $24 \mathrm{~cm}$ & ca. $2 \mathrm{~m}$ & 26 & $1.5-8 \mathrm{~m}$ & SW-S \\
\hline 2 & $22 \mathrm{~cm}$ & ca. $3 \mathrm{~m}$ & 33 & $3-8 \mathrm{~m}$ & SW-S \\
\hline 3 & $26 \mathrm{~cm}$ & $\begin{array}{l}\text { not charred } \\
\text { oförkolnad }\end{array}$ & 38 & $7-10 \mathrm{~m}$ & WSW-SE \\
\hline 4 & $24 \mathrm{~cm}$ & $<1 \mathrm{~m}$ & 16 & $1-6 \mathrm{~m}$ & S-SE \\
\hline 5 & $25 \mathrm{~cm}$ & $<1 \mathrm{~m}$ & 25 & $1-6 \mathrm{~m}$ & SW \\
\hline 6 & $25 \mathrm{~cm}$ & ca. $2 \mathrm{~m}$ & 22 & $1-7 \mathrm{~m}$ & SW-ESE \\
\hline 7 & $27 \mathrm{~cm}$ & $\begin{array}{l}\text { not charred } \\
\text { oförkolnad }\end{array}$ & 26 & $3-8 \mathrm{~m}$ & SW-ESE \\
\hline 8 & $26 \mathrm{~cm}$ & $\begin{array}{l}\text { not charred } \\
\text { oförkolnad }\end{array}$ & 18 & $2-6 \mathrm{~m}$ & SW-SE \\
\hline 9 & $28 \mathrm{~cm}$ & ca. $2 \mathrm{~m}$ & 21 & $3-6 \mathrm{~m}$ & SW \\
\hline 10 & $22 \mathrm{~cm}$ & $<1 \mathrm{~m}$ & 2 & $3.5-5 \mathrm{~m}$ & SSW \\
\hline 11 & $20 \mathrm{~cm}$ & $<1 \mathrm{~m}$ & 15 & $2-3 \mathrm{~m}$ & SSW-S \\
\hline
\end{tabular}

actively during three weeks after the fire to early June, but then their use clearly decreased. The activity period matches the pre-nesting season of the local pair; which was forced to delay its nesting attempt because the nest cavity was taken over by the Great Spotted Woodpecker Dendrocopos major, and they were not able to start nesting until in early June.

The reported case shows that a fire-related damage to conifer trees may be advantageous for the woodpeckers also due to the increased sap provision. Thus, in addition to the previously documented positive effects via the increased availability of bark beetles after fire, the Three-toed Woodpecker shows remarkable flexibility in taking advantage of disturbance-driven dynamic forest landscapes.

\section{Acknowledgements}

Lammi Biological Station provided excellent working facilities to TP during the field season.

\section{References}

Alexou, M. \& Dimitrakopoulos, A.P. 2014. Early physiological consequences of fire as an abiotic stressor in metabolic source and sink of young Brutian pine (Pinus brutia Ten.). Tree Physiology 34: 1388-1398.
Bukkens, S.G.F. 1997. The nutritional value of edible insects. Ecology of Food and Nutrition 36: 287-319.

Cramp, S. (ed.) 1985: Handbook of the birds of Europe, the Middle East and North Africa. Vol. 4. Oxford University Press, Oxford.

Douglas, A.E. 2006. Phloem sap feeding by animals: problems and solutions. J. Exp. Bot. 57: 747-754.

Eberhardt, L.S. 2000. Use and selection of sap trees by Yellow-bellied Sapsuckers. Auk 117: 41-51.

Fayt, P., Machmer, M.M. \& Steeger, C. 2005. Regulation of spruce bark beetles by woodpeckers - a literature review. For. Ecol. Manage. 206: 1-14.

Glutz von Blotzheim, U.N. \& Bauer, K.M. 1980. Handbuch der Vögel Mitteleuropas. Vol 9. Akademische Verlagsgesellschaft, Frankfurt a.M.

Hyvärinen, E., Kouki, J., Martikainen, P. \& Lappalainen, H. 2005. Short-term effects of controlled burning and greentree retention on beetle (Coleoptera) assemblages in managed boreal forests. For. Ecol. Manage. 212: 315-332.

Kilham, L. 1964. The relations of breeding Yellow-bellied Sapsuckers to wounded birches and other trees. Auk 781: 520-527.

Muona J. \& Rutanen, I. 1994. The short-term impact of fire on the beetle fauna in boreal conifer forest. Ann. Zool. Fennici 31: 109-121.

Núñes Montellano, M.G. \& Blendinger, P.G. 2016. Selection of plants for sap feeding by the White-fronted Woodpecker Melanerpes cactorum in Chaco dry forest, Argentina. Acta Orn. 51: 105-122.

Pakkala, T., Tiainen, J. \& Kouki, J. 2017. The importance of 
Table 2. The activity of the Three-toed Woodpeckers at the sap trees of the burned area.

De tretåiga hackspettarnas aktiviteter på savträden i brandområdet.

\begin{tabular}{|c|c|c|}
\hline $\begin{array}{l}\text { Observation time } \\
\text { (Date; number of days after burning; } \\
\text { length of observation time) } \\
\text { Observationtid } \\
\text { (Datum; antal dagar efter branden; } \\
\text { längden av observationen) }\end{array}$ & Aktiviteten av tretåiga hackspettar & The amount of sap rows \\
\hline 11.5.; 1 day; $2 \mathrm{~h}$ (afternoon) & $\begin{array}{l}\text { Male and female at sap trees ca. half of the } \\
\text { observation time }\end{array}$ & ca. 15 rows started in 5 trees \\
\hline 11.5.; 1 dag; 2 h (eftermiddag) & $\begin{array}{l}\text { Hanen och honan vid savtallarna omkring } \\
\text { hälften av observationstiden }\end{array}$ & $\begin{array}{l}\text { ca. } 15 \text { påbörjade rader på } 5 \\
\text { träd }\end{array}$ \\
\hline 14.5.; 4 days; 5 h (morning) & $\begin{array}{l}\text { Male and female actively at sap rows most of the } \\
\text { observation time }\end{array}$ & $\begin{array}{l}\text { ca. } 70 \text { rows in } 9 \text { trees, part of } \\
\text { the rows unfinished }\end{array}$ \\
\hline 14.5.; 4 dagar; 5 h (morgon) & $\begin{array}{l}\text { Hanen och honan aktivt vid savraderna } \\
\text { mestadelen av observationstiden }\end{array}$ & $\begin{array}{l}\text { ca. } 70 \text { rader på } 9 \text { träd, några } \\
\text { av dem halvgjorda }\end{array}$ \\
\hline 21.5.; 11 days; $4 \mathrm{~h}$ (morning) & $\begin{array}{l}\text { Male and female at sap rows ca. half of the } \\
\text { observation time }\end{array}$ & $\begin{array}{l}130 \text { rows in } 11 \text { trees, part of } \\
\text { the rows unfinished }\end{array}$ \\
\hline 21.5.; 11 dagar; 4 h (morgon) & $\begin{array}{l}\text { Hanen och honan vid savraderna omkring } \\
\text { hälften av observationstiden }\end{array}$ & $\begin{array}{l}130 \text { rader på } 11 \text { träd, några av } \\
\text { dem halvgjorda }\end{array}$ \\
\hline 25.5.; 15 days; 2 h (morning) & $\begin{array}{l}\text { Male and female mostly at separate times at sap } \\
\text { rows ca. } 30 \% \text { of observation time }\end{array}$ & $\begin{array}{l}160 \text { rows in } 11 \text { trees, part of } \\
\text { the rows unfinished }\end{array}$ \\
\hline 25.5.; 15 dagar; 2 h (morgon) & $\begin{array}{l}\text { Hanen och honan mestadels separat vid } \\
\text { savraderna ca. } 30 \% \text { av observationstiden }\end{array}$ & $\begin{array}{l}160 \text { rader på } 11 \text { träd, några av } \\
\text { dem halvgjorda }\end{array}$ \\
\hline $\begin{array}{l}\text { 2.6.; } 23 \text { days; } 2+1 \mathrm{~h} \text { (morning, } \\
\text { afternoon) }\end{array}$ & $\begin{array}{l}\text { Male occasionally at sap rows in the morning, } \\
\text { no observations in the afternoon }\end{array}$ & 215 rows in 11 trees \\
\hline $\begin{array}{l}\text { 2.6.; } 23 \text { dagar; } 2+1 \text { h (morgon, } \\
\text { eftermiddag) }\end{array}$ & $\begin{array}{l}\text { Hanen sporadiskt vid savraderna på morgonen, } \\
\text { inga observationer på eftermiddagen }\end{array}$ & 215 rader på 11 träd \\
\hline $\begin{array}{l}22.6 . ; 43 \text { days; } 1+1 \mathrm{~h} \text { (morning, } \\
\text { afternoon) }\end{array}$ & No woodpeckers observed at sap trees & 242 rows in 11 trees \\
\hline $\begin{array}{l}\text { 22.6.; } 43 \text { dagar; } 1+1 \mathrm{~h} \text { (morgon, } \\
\text { eftermiddag) }\end{array}$ & Inga hackspettar vid savträd & 242 rader på 11 träd \\
\hline
\end{tabular}

nesting cavity and tree reuse of the Three-toed Woodpecker Picoides tridactylus in dynamic forest landscapes. Ann. Zool. Fennici 54: 154-175.

Pate, J., Shedley, E., Arthur, D. \& Adams, M. 1998. Spatial and temporal variations in phloem sap composition of plantation-grown Eucalyptus globulus. Oecologia 117: 312-322.

Pechacek, P. 2006. Foraging behaviour of Eurasian Threetoed Woodpeckers (Picoides tridactylus alpinus) in relation to sex and season in Germany. Auk 123: 312-322.

Ruge, K. 1968. Zur Biologie des Dreizehenspechtes Picoides tridactylus. 1. Beobachtungsgebiet, Aktionsgebiet, Nahrungserwerb, Trommeln, Pendelwegungen. Orn. Beob. 65: 109-124.

White, T.C.R. 1984. The abundance of invertebrate herbivores in relation to the availability of nitrogen in stressed food plants. Oecologia 63: 90-105.

\section{Sammanfattning}

Den tretåiga hackspetten Picoides tridactylus lever av insekter och allehanda andra artropoder men särskilt från förvåren till början av häckningen använder den också sav som föda, särskilt från gran och tall. Saven är rik på energi och näring i form av sockerarter, aminosyror och mineraler. Saven lagras i parenkymceller i trädens floem och hackspetten kommer åt saven genom små hål, som den hackar, ofta i rader på stammens solsida (så kallad savrad), och sådana träd kan användas under flera år. Det är känt att tretåiga hackspettar, och även andra hackspettar, lockas till områden som drabbats av skogsbrand. Den vanliga tolkningen är att det är ökad förekomst av insekter efter en brand som lockar till sig hackspettarna. Men denna effekt kan normalt inte upptäckas förrän efter någon tid. I denna uppsats visar vi att det också kan vara saven som attraherar och att man då får en omedelbar effekt.

I samband med en långtidsstudie av savanvändning observerades i Evo i södra Finland våren 2016 hur ett lokalt par av tretåig hackspett omedelbart började använda sav från brandskadade tallar i en liten grupp (37 ca. 40-åriga tallar) som lämnats vid en hyggesbränning. Branden passerade genom det sparade tallbeståndet och många tallars bark för- 
kolnade till en höjd av 2-3 meter på den sida från vilken branden kom. Hyggesbränningen genomfördes den 10 maj 2016 och användningen av sav började genast dagen efter branden och fortsatte intensivt under tre veckor. Från fyra dagar efter bränningen och framåt kunde hackspettarna tillbringa flera timmar i talldungen med att hacka nya hål och dricka sav. Hackspettarna använde elva av de trettiosju tallarna, som hade en brösthöjddiameter på 20-28 cm. Savhålen hackades på sydsidan av stammen, vilket var den kraftigast brända sidan. Vanligen hackades de nya hålen ovanför gamla hål.

Det aktuella hackspettparet var redan före bränningen i färd med att använda sav från granar utanför brandhygget men hade inte observerats använda tallarna i den sparade dungen. Antagligen lockades hackspettarna av de brända tallarnas fysiologiska reaktion. Hettan är en stressfaktor som observerats förorsaka förändringar i savens sammansättning, till exempel ökat innehåll av kväve, aminosyror, protein och sockerarter samt även ökat savflöde. Att spettarna hackade nya hål ovanför gamla kan förklaras av att sav eller värdefulla komponenter i saven ackumuleras ovanför de skadade partierna av barken.

Man har inte tidigare observerat att den tretåiga hackspetten reagerar så omedelbart att utnyttja brandskadade träd. Den snabba övergången till att använda tallsav på brandytan visar på beteendets flexibilitet, som är en del av anpassningen till den boreala skogens störningsdynamik. 